\section{Phosphorus Rate, Leaching Fraction, and Substrate Influence on Influent Quantity, Effluent Nutrient Content, and Response of a Containerized Woody Ornamental Crop}

\author{
James S. Owen, Jr. ${ }^{1,4}$ \\ Oregon State University, North Willamette Research and Extension Center, \\ 15210 NE Miley Road, Aurora, OR 97002-9543
}

Stuart L. Warren ${ }^{2}$

Department of Horticulture, Forestry, and Recreation Resources, Kansas State University, Manhattan, KS 66506

Ted E. Bilderback ${ }^{2}$

Department of Horticultural Science, North Carolina State University, Raleigh, NC 27695-7609

\section{Joseph P. Albano ${ }^{3}$}

U.S. Department of Agriculture, Agricultural Research Service, U.S. Horticulture Research Laboratory, 2001 South Fork Road, Fort Pierce, FL 34945

Additional index words. clay, Cotoneaster dammeri 'Skogholm', irrigation, pine bark, runoff, sand, water use

\begin{abstract}
Production of containerized nursery crops requires high inputs of water and mineral nutrients to maximize plant growth to produce a salable plant quickly. However, input efficiencies remain below $50 \%$ resulting in major quantities of water and nutrients leached. This study was conducted to determine if production factors could be altered to increase water and phosphorus uptake efficiency (PUE) without sacrificing plant growth. The effects of a pine bark substrate amendment (clay or sand) and a 50\% reduction in both $P$ application rate $(1.0 \mathrm{~g}$ or $0.5 \mathrm{~g})$ and leaching fraction $(\mathrm{LF}=$ effluent $\div$ influent $)$ $(0.1$ or 0.2) were investigated. Containerized Skogholm cotoneaster (Cotoneaster dammeri Schnied. 'Skogholm') was grown on gravel floor effluent collection plots that allowed for calculation of water and nutrient budgets. Pine bark amended with $11 \%$ (by vol.) Georgiana 0.25 to $0.85 \mathrm{~mm}$ calcined palygorksite-bentonite mineral aggregate (clay) increased available water $4 \%$ when compared with pine bark amended with $11 \%$ (by volume) coarse sand. Decreasing LF from 0.2 to 0.1 reduced cumulative container influent $25 \%$ and effluent volume $64 \%$, whereas total plant dry weight was unaffected by LF. Reduction of target $\mathrm{LF}$ from 0.2 to 0.1 reduced dissolved reactive $P$ concentration and content by $8 \%$ and $64 \%$, respectively. In a sand-amended substrate, total plant dry weight decreased $16 \%$ when $1.0 \times P$ rate was reduced to $0.5 \times P$, whereas total plant dry weight was unaffected by rate of $P$ when pine bark was amended with clay. Plant content of all macronutrients, with the exception of $\mathrm{N}$, increased when pine bark was amended with clay versus sand. Reducing $P$ rate from $1.0 \times$ to $0.5 \times$ increased PUE $54 \%$ or $11 \%$ in a clay or sand-amended substrate, respectively. Amending pine bark with $11 \%$ (by volume) 0.25 to $0.85 \mathrm{~mm}$ calcined palygorksite-bentonite mineral aggregate produced an equivalent plant with half the $P$ inputs and a $0.1 \mathrm{LF}$, which reduced water use $25 \%$ and $P$ effluent losses $42 \%$ when compared with an industry representative substrate [8 pine bark : 1 sand (11\% by volume)].
\end{abstract}

Received for publication 27 Nov. 2007. Accepted for publication 23 Feb. 2008.

Research was funded in part by USDA-ARS Floriculture and Nursery Initiatives grants (SCA \#58-66182-2027), Horticulture Research Institute, North Carolina Association of Nurserymen, and Oil-Dri Corporation of America.

We thank Mary Lorscheider, William Reece, and Kristen Walton for technical assistance and William H. Swallow for statistical assistance.

${ }^{1}$ Assistant Professor.

${ }^{2}$ Professor.

${ }^{3}$ Research Horticulturist.

${ }^{4}$ To whom reprint requests should be addressed; e-mail jim.owen@oregonstate.edu
Mineral nutrient management strategies in containerized crop production are based on the "Sprengel-Liebig law of the minimum" (Epstein and Bloom, 2005) as noted by LeaCox and Ristvey (2003). Thus, excessive mineral nutrients are supplied to ensure plant growth is not restricted. The negative impacts (i.e., leaching and runoff) of this strategy are more pronounced in containerized crop production where nutrient uptake efficiencies are low because of the relatively inert substrates used as growing medium. This management strategy needs to be reconsidered as a result of economic and environmental concerns surrounding current production practices. Phosphorus losses are being investigated because $\mathrm{P}$ leaching or runoff can contribute to eutrophication, loss of aquatic biota, and hypoxia (Brady and Weil, 1999). The U.S. Environmental Protection Agency (USEPA) has proposed water quality criteria for maximum total $\mathrm{P}$ concentration to be $0.025 \mathrm{mg} \cdot \mathrm{L}^{-1}$ or less within lakes or reservoirs (USEPA, 1986). Substrate solution $P$ concentrations of 5 to $10 \mathrm{mg} \cdot \mathrm{L}^{-1}$ are recommended currently by Best Management Practices (BMPs) (Yeager et al., 1997). These rates exceed the USEPA water quality criteria by 200 - to 400-fold. Under current BMP recommendations, $\mathrm{P}$ uptake efficiency (PUE) ranges from $34 \%$ to $45 \%$ (Lea-Cox and Ristvey, 2003; Warren et al., 1995). Therefore, 55\% or greater of applied $\mathrm{P}$ is not used by the plant in containerized production. Nursery management practices and infrastructure need to be adjusted to increase nutrient uptake efficiency and reduce nutrient loss. Warren and Bilderback (2005) reported irrigation management and nutrient uptake efficiency are directly interrelated. Unlike N, P leachate losses were unaffected by $\mathrm{P}$ application rate, but were affected by leaching fraction (LF) and P source. Tyler et al. (1996) decreased effluent $\mathrm{P}$ content by $58 \%$ when growing Skogholm cotoneaster (Cotoneaster dammeri Schnied. 'Skogholm') in a pine bark substrate with a low (0.0 to 0.2$)$ versus high (0.4 to 0.6$) \mathrm{LF}$.

Use of controlled-release fertilizers (CRFs) has increased mineral nutrient use efficiency by supplying nutrients corresponding with plant demand and minimizing pathways of losses (e.g., microbial transformation, soil fixation, and leaching), thus decreasing environmental impact (Shaviv and Mikkelsen, 1993). Warren et al. (1995) reported resin-coated CRF $P$ resulted in the highest PUE (43\%) by maintaining a low, constant rate of $\mathrm{P}$ loss at $\approx 1 \mathrm{mg} \cdot \mathrm{d}^{-1}$ when Sunglow azalea [Rhododendron L. 'Sunglow' (Carla hybrid)] was grown in 3.8-L containers with a pine bark substrate. LeaCox and Ristvey (2003) suggested containerized $\mathrm{P}$ application be reduced $80 \%$, thus making the optimal substrate solution $\mathrm{P}$ concentration $2 \mathrm{mg} \cdot \mathrm{L}^{-1}$ or less and increasing PUE to $75 \%$ when adequate $\mathrm{N}$ was applied. This decrease in substrate solution $\mathrm{P}$ concentration has been reported not to affect plant growth (Lea-Cox and Ristvey, 2003). Implementing these suggested $\mathrm{P}$ reductions still 
result in $\mathrm{P}$ concentrations that remain 40 - to 80 -fold greater than USEPA criteria for public surface waters.

Current BMP recommendations are based, in part, on research conducted by Yeager and Wright (1982) who reported a $23 \%(1 \mathrm{~g})$ increase in top dry weight Helleri holly (Ilex crenata Thunb. 'Helleri') when substrate solution $\mathrm{P}$ was increased from 0 to $10 \mathrm{mg} \cdot \mathrm{L}^{-1}$. They also reported that root dry weight of Helleri holly was unaffected by $\mathrm{P}$ concentration. In contrast, Groves et al. (1998b) reported that current BMP substrate solution $\mathrm{P}$ recommendations could not be maintained when irrigating 3.8 -L containerized Skogholm cotoneaster with $800 \mathrm{~mL} \cdot \mathrm{d}^{-1}$; however, top and root dry weight (Groves et al., 1998a) were maximized at $800 \mathrm{~mL} \cdot \mathrm{d}^{-1}$ although observed substrate solution $\mathrm{P}$ concentrations values fell to as low as 1.8 and $0.1 \mathrm{mg} \cdot \mathrm{L}^{-1} \mathrm{P}$ at 60 and $114 \mathrm{~d}$ after initiation of the experiment, respectively.

Another approach to reduce $\mathrm{P}$ losses and increase PUE is to modify the container substrate. Williams and Nelson (1997) investigated various clays (palygorskite and arcillite) and brick chips as precharged sources of $\mathrm{P}$ in peat:perlite substrates. The palygorskite clay absorbed $77 \%$ more $\mathrm{P}$ than the other materials. In a subsequent study, $P$ leachate was reduced by amending the substrate with a precharged palygorskite (6\% $\mathrm{P}$ leached) as compared with arcillite $(18 \% \mathrm{P}$ leached), brick chips (11\% P leached), or a peat:perlite substrate (37\% P leached) (Williams and Nelson, 2000). In a similar study, Zhang et al. (2002) used alumina-buffered $\mathrm{P}$ as a $\mathrm{P}$ source, which decreased effluent $\mathrm{P} 60 \%$ or greater when compared with resin-coated $\mathrm{P}$ applied across four tree and shrub species grown in 7.6-L containers with a peat substrate. Therefore, our objective was to determine the effect of substrate amendment in combination with a $50 \%$ reduction in $\mathrm{P}$ application rate and leaching fraction on mineral nutrient and water efficiency and plant response when producing a containerized nursery crop in a pine bark-based substrate.

\section{Materials and Methods}

Experimental design. The experiment was a 2 (substrate amendment) $\times 2(\mathrm{LF}) \times 2(\mathrm{P}$ rate) factorial in a randomized complete block design with four replications with 10 plants per replication. The two substrates consisted of pine bark amended with a mineral aggregate or coarse, washed builder's sand at $11 \%$ (by volume). The mineral aggregate (clay) was a 0.25 to $0.85 \mathrm{~mm}$ calcined, low volatile material palygorksitebentonite from Ochlocknee, GA (Oil-Dri Corp. of America, Chicago) (Moll and Goss, 1997). The two target LFs were 0.20 and 0.10 and two rates of $\mathrm{P}$ were $1.0 \times$ (recommended rate) and $0.5 \times$. The experiment was conducted from 25 May 2004 to 16 Sept. 2004 at the Horticulture Field Laboratory. (lat. $35^{\circ} 47^{\prime} 37^{\prime \prime} \mathrm{N}$; long. $78^{\circ} 41^{\prime} 59^{\prime \prime} \mathrm{W}$ ) located at North Carolina State University, Raleigh.
Water and nutrient management. Uniform, rooted stem cuttings of Skogholm cotoneaster were potted into 14-L black containers (C-2000; Nursery Supplies, Chambersburg, PA) on 15 May 2004. Containers were top-dressed on 25 May 2004 [0 d after experiment initiation (DAI)] with $54 \mathrm{~g} 19 \mathrm{~N}-0.9 \mathrm{P}-6.4 \mathrm{~K}$ or $19 \mathrm{~N}-1.8 \mathrm{P}-6.4 \mathrm{~K}$ $\left(19 \mathrm{~N}-2 \mathrm{P}_{2} \mathrm{O}_{5}-8 \mathrm{~K}_{2} \mathrm{O}\right.$ or $19 \mathrm{~N}-4 \mathrm{P}_{2} \mathrm{O}_{5}-8 \mathrm{~K}_{2} \mathrm{O}$ 6-month CRF; Harrell's, Lakeland, FL) for the $0.5 \times\left(0.5-\mathrm{g} \mathrm{container}^{-1}\right)$ or $1.0 \times(1.0-\mathrm{g}$ container $\left.^{-1}\right) \mathrm{P}$ application rate, respectively. The $1.0 \times$ rate also received $3 \mathrm{~g}$ of A-Turf [20\% calcium $(\mathrm{Ca})$ filler; Harrell's] to maintain equivalent $1.5 \mathrm{~g} \mathrm{Ca}$ addition per container. Fertilizer was hand-incorporated into the surface $3 \mathrm{~cm}$ of the substrate. For one plant per plot, CRF was divided into two $6 \mathrm{~cm} \times 10-\mathrm{cm}$ bags made from nylon mesh (No-See-Um Mosquito Net; REI, Sumner, WA; Catalog Number 601044). Mesh bags were placed on the substrate surface and partially covered with substrate to simulate top dressing and hand-incorporation, respectively. This CRF was used for quantification of nutrients remaining in the CRF at the completion of the study. All substrates were amended with a $0.6-\mathrm{kg} \cdot \mathrm{m}^{-3}$ blend of pulverized and ground dolomitic limestone $\left[\mathrm{CaMg}\left(\mathrm{CO}_{3}\right)_{2}\right]$. The containers were placed on 32 separate plots, 10 containers per plot. Two of the four replications per treatment were placed on effluent collection plots, which allowed for collection of all effluent leaving each plot. Plots were $8 \times 1 \mathrm{~m}$ with a $2 \%$ slope. On the 16 effluent collection plots, effluent was measured daily from irrigation water applied through pressure-compensated spray stakes [Acu-Spray Stick; Wade Mfg. Co., Fresno, CA $\left.\left(200 \mathrm{~mL} \cdot \mathrm{min}^{-1}\right)\right]$. Irrigation was applied in a cyclic manner with the irrigation volume divided equally among three applications applied at 0200, 0400, and $0600 \mathrm{HR}$ eastern daylight time. Irrigation volume (influent) to maintain a 0.20 or 0.10 LF (Eq. [1]) was applied to each plot based on effluent collected from each of the 16 individual effluent collection plots, where effluent values were monitored daily and influent volumes were monitored biweekly.

$$
\mathrm{LF}=\frac{\text { effluent volume }(\mathrm{mL})}{\text { influent volume }(\mathrm{mL})}
$$

These data were used to determine water volume and water use as affected by each treatment. From these data, water application efficiency (WAE, Eq. [2]), time averaged application rate (TAAR, Eq. [3]), and water use efficiency of productivity $\left(\mathrm{WUE}_{\mathrm{P}}, \mathrm{Eq}\right.$. [4]) were calculated.

$$
\begin{aligned}
\text { WAE }= & {\left[\frac{\text { volume retained in substrate }(\mathrm{mL})}{\text { influent volume }(\mathrm{mL})}\right] } \\
& \times 100 \\
\mathrm{TAAR}= & \frac{\text { daily influent volume }(\mathrm{mL})}{\text { application duration time }(\mathrm{min})}
\end{aligned}
$$

$\mathrm{WUE}_{\mathrm{P}}=\frac{\text { volume retained in substrate }(\mathrm{mL})}{\text { total plant dry mass }(\mathrm{g})}$

Effluent and substrate analysis. An aliquot of the daily collected effluent was analyzed colorimetrically using an ultraviolet-visible spectrophotometer (Spectronic 1001 Plus; Milton Roy Co., Rochester, NY) for dissolved reactive P (DRP) (Murphy and Riley, 1962). At the conclusion of the study, available substrate total DRP was extracted from the substrate using a 1 substrate:1.5 extract $\left(115 \mathrm{~cm}^{3}\right.$ substrate: $175 \mathrm{~mL}$ deionized water) (Sonneveld et al., 1974). The extractant was deionized water in which the substrate dilution was shaken for $1 \mathrm{~h}$ and filtered through a syringe-driven Millex-HPF HV nonsterile filter, $0.45 \mu \mathrm{m}, \mathrm{PVDF}, 25 \mathrm{~mm}$ (Millipore Corp., Billerica, MA). An aliquot of the filtered solution was analyzed on the spectrophotometer to quantify the DRP held in the substrate.

DRP remaining in the fertilizer prills at the end of the study was measured as follows. Prills were removed from mesh bags. Nutrients were extracted from fertilizer prills by blending them in $200 \mathrm{~mL}$ of deionized water. After blending, the liquid was transferred quantitatively to a 1-L volumetric flask and adjusted to volume with deionized water before taking an aliquot of the extractant supernatant. Fertilizer prill extract was filtered and DRP quantified using the spectrophotometer as described previously.

Plant response. At 114 DAI (21 Sept. 2004), tops from two randomly chosen containers per plot (total of eight plants per treatment) were harvested. Roots were placed over a screen and washed with a highpressure water stream to remove substrate. Tops and roots were dried at $60^{\circ} \mathrm{C}$ for $5 \mathrm{~d}$ and weighed. After drying, all leaves were removed from one top per replication and weighed. As a result of their size, tops (stems + leaves) were ground initially using a Model 4 bench, 1-horsepower Wiley Mill ${ }^{\circledR}$ (Thomas Scientific, Swedesboro, NJ) to pass a $6-\mathrm{mm}$ sieve. The ground tops and unground roots were then ground separately through a Foss Tecator Cyclotec ${ }^{\mathrm{TM}} 1093$ sample mill (Analytical Instruments, LLC, Golden Valley, $\mathrm{MN}$ ) to pass a $0.5-\mathrm{mm}$ sieve. Roots and tops were analyzed for $\mathrm{N}, \mathrm{P}, \mathrm{K}, \mathrm{Ca}$, magnesium $(\mathrm{Mg})$, sulfur (S), boron (B), copper, iron ( $\mathrm{Fe})$, manganese $(\mathrm{Mn})$, and zinc by the Agronomic Division of the North Carolina Department of Agriculture. A P nutrient budget was developed for each treatment (Eq. [5]).

$$
\begin{aligned}
& \mathrm{P}(\mathrm{mg})=\sum_{P} \text { (plant }+ \text { effluent }+ \\
& \text { substrate }+ \text { fertilizer prills) }
\end{aligned}
$$

which included $\mathrm{P}$ absorbed by plant, loss in effluent, remaining in the substrate, or remaining in the fertilizer prill. The nutrient budget was used to calculate $\mathrm{P}$ uptake efficiency (PUE, Eq. [6]). 
PUE $=\left[\frac{\text { plant absorbed }(\mathrm{mg})}{\operatorname{applied~CRF~P~}(\mathrm{mg})-\text { remaining CRF P }(\mathrm{mg})-\text { substrate P }(\mathrm{mg})}\right] \times 100$

Substrate physical properties. Ten cylindrical aluminum cores, five $347.5 \mathrm{~cm}^{3}$ (7.6 $\mathrm{cm}$ height $\times 7.6 \mathrm{~cm}$ diameter) and five 100 $\mathrm{cm}^{3}$ (2.5 cm height $\times 7.6 \mathrm{~cm}$ diameter), were placed in four fallow containers of each substrate. These containers were placed adjacent to the plants in the research study and received equivalent irrigation and rainfall as the corresponding treatments. After 9 weeks, the $347.5-\mathrm{cm}^{3}$ cores were extracted and total porosity (TP), container capacity (CC), available water capacity (AW), and air-filled porosity (AS) were determined using the NCSU Porometer ${ }^{\mathrm{TM}}$ as described by Fonteno and Bilderback (1993). Unavailable water (UW), water held in the substrate at 1.5 $\mathrm{MPa}$ or higher, was determined with the $100-\mathrm{cm}^{3}$ cores through a procedure developed by Milks et al. (1989). Bulk density $\left(\mathrm{D}_{\mathrm{b}}\right)$ was determined using oven-dried $\left(110^{\circ} \mathrm{C}\right)$ substrate in the $347.5-\mathrm{cm}^{3}$ cores.

Data analysis. All data were subjected to analysis of variance procedures in SAS version 8.01 (SAS Inst., Cary, NC) with $P \leq$ 0.10 to reduce the risk of a Type II error (Marini, 1999). All three-way interactions were not significant and any significant twoway interactions are presented in tables and figures. PROC REG and PROC NLIN were used to investigate the linear and nonlinear segmented trends associated with water and nutrient data $(P \leq 0.05)$. Join points or end points for segmented lines are denoted as $X_{n}$. When significant, simple linear and polynomial curves were fit to data. The maximum of the polynomial was calculated as the zero point in a first-order derivative of the independent variable. PROC CORR was used to investigate correlations between water and nutrient data.

\section{Results and Discussion}

Substrate physical properties. Calcined clay amendment increased TP, CC, and AW $4 \%, 6 \%$, and $4 \%$, respectively, compared with sand amendment (Table 1). Riviere et al. (1990) showed a similar 4\% increase in TP when increasing clay content $6 \%$ from 4 clay : 1 peat to 6 clay : 1 peat. The increase in $\mathrm{AW}$ translated into $0.5 \mathrm{~L}$ more $\mathrm{AW}$ in a 14-L container compared with the sandamended substrate. This is most likely a function of the $6 \%$ increase in CC (Table 1). AS and UW were unaffected by substrate amendment. In contrast, Carlile and Bedford (1988) reported AS increased when a peatbased substrate was amended with $20 \%$, $35 \%$, or $50 \%$ (by volume) calcined or fired clay illustrating the differences between pine bark and peat.

Substrate $D_{b}$ decreased $31 \%\left(0.11 \mathrm{~g} \cdot \mathrm{cm}^{-3}\right)$ when pine bark was amended with clay versus an equivalent volume of sand (Table $1)$, which reduced container (14 L) weight at $100 \% \mathrm{CC}$ by $750 \mathrm{~g}$ (data not presented).
Thus, clay-amended substrate did not increase container weight compared with sand.

Water use. Cumulative container influent volume decreased $26 \%(26 \mathrm{~L})$ or $24 \%$ (21 L) when decreasing LF from 0.2 to 0.1 in a clay or sand-amended substrate, respectively (Table 2). Tyler et al. (1996) reported a $25 \%$ to $40 \%(19 \mathrm{~L})$ decrease in influent volume when growing Skogholm cotoneaster in a $3.8-\mathrm{L}$ container irrigated to maintain a low ( 0.0 to 0.2$)$ compared with a high ( 0.4 to 0.6) target LF for $100 \mathrm{~d}$. LF, averaged over substrate, was $0.11 \pm 0.008 \mathrm{SE}$ and $0.24 \pm$ $0.004 \mathrm{SE}$ when attempting to maintain a 0.1 or 0.2 target LF, respectively, for the growing season $(114 \mathrm{~d})$.

Before 75 DAI, influent was unaffected by substrate or LF averaging $0.5 \mathrm{~L}$ per day (Fig. 1A). Apparently, evapotranspiration was low enough that treatments had no impact. However, influent needed to maintain a 0.1 target LF increased $100 \%$ and $80 \%$ after $75 \mathrm{DAI}$ to 1.0 or $0.9 \mathrm{~L} \cdot \mathrm{d}^{-1}$ container $^{-1}$ for the clay and sand-amended substrate, respectively (Fig. 1A). Similarly, influent to maintain a 0.2 target LF at 75 DAI increased $180 \%$ or $140 \%$ in a clay- $\left(1.4 \mathrm{~L} \cdot \mathrm{d}^{-1}, 5.8 \mathrm{~mL} \cdot \mathrm{min}^{-1}\right)$ or sand- $\left(1.2 \mathrm{~L} \cdot \mathrm{d}^{-1}, 5.0 \mathrm{~mL} \cdot \mathrm{min}^{-1}\right)$ amended substrate, respectively.

Table 1. Physical properties $(n=5)$ of pine bark substrate amended with $11 \%$ (by vol.) coarse sand or $0.85 \mathrm{~mm}$ to $0.25 \mathrm{~mm}$ Georgiana bentonite-palygorksite mineral aggregate. ${ }^{2}$

\begin{tabular}{|c|c|c|c|c|c|c|}
\hline \multirow[b]{2}{*}{ Substrate } & \multirow{2}{*}{$\begin{array}{c}\text { Bulk } \\
\text { density } \\
\left(\mathrm{g} \cdot \mathrm{cm}^{-3}\right)\end{array}$} & $\begin{array}{l}\text { Total }^{\mathrm{y}} \\
\text { porosity }\end{array}$ & $\begin{array}{c}\text { Container } \\
\text { capacity }\end{array}$ & $\begin{array}{l}\text { Air }^{\mathrm{w}} \\
\text { space }\end{array}$ & $\begin{array}{c}\text { Availablev }^{v} \\
\text { water }\end{array}$ & $\begin{array}{c}\text { Unavailable }^{\mathrm{u}} \\
\text { water }\end{array}$ \\
\hline & & \multicolumn{5}{|c|}{ 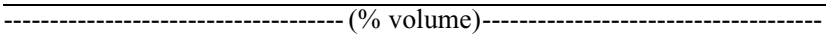 } \\
\hline$\overline{\text { Clay }}$ & 0.24 & 86 & 63 & 23 & 37 & 25 \\
\hline Sand & 0.35 & 82 & 57 & 25 & 33 & 24 \\
\hline$P$ value & 0.0001 & 0.0001 & 0.0001 & 0.18 & 0.0001 & 0.09 \\
\hline
\end{tabular}

${ }^{\mathrm{z}}$ All substrates lay fallow under experimental field conditions for $60 \mathrm{~d}$ before analysis.

yercent volume at $0.4 \mathrm{kPa}$.

xPredicted as percent volume at drainage.

${ }^{\mathrm{w}}$ Air space $=$ total porosity - container capacity.

${ }^{\mathrm{v}}$ Available water $=$ container capacity - unavailable water.

uPercent volume at $1500 \mathrm{kPa}$.

Table 2. Effect of target leaching fraction (LF) and substrate amendment (clay or sand) on influent volume, water retention, and leaching fraction (LF) for Skogholm cotoneaster grown $114 \mathrm{~d}$ in pine bark amended with $11 \%$ (by vol.) sand or 0.25 to $0.85 \mathrm{~mm}$ Georgiana bentonite-palygorksite mineral aggregate (clay).

\begin{tabular}{|c|c|c|c|c|c|c|c|}
\hline \multirow[b]{2}{*}{ Target LF } & \multicolumn{3}{|c|}{ Influent $^{2}(\mathrm{~L})$} & & \multicolumn{3}{|c|}{ Calculated LFy } \\
\hline & Clay & Sand & $P$ value & & Clay & Sand & Mean \\
\hline 0.10 & $74^{x}$ & 67 & 0.03 & & $0.10^{\mathrm{w}}$ & 0.12 & $0.11 \mathrm{~B}^{\mathrm{v}}$ \\
\hline 0.20 & 100 & 88 & 0.01 & & 0.24 & 0.25 & $0.24 \mathrm{~A}$ \\
\hline & 0.0001 & 0.0008 & & Mean & $0.17 \mathrm{~b}$ & $0.19^{\mathrm{u}}$ & \\
\hline
\end{tabular}

${ }^{2}$ Target LF and substrate interaction significant, determined by analysis of variance $(P \leq 0.10)$.

${ }^{\mathrm{y}}$ Target $\mathrm{LF}$ and substrate interaction nonsignificant $(P>0.10)$.

${ }^{x} \sum$ (influent volume) for $114 \mathrm{~d}$, pooled over P application rate of $0.5 \mathrm{~g}$ or $1.0 \mathrm{~g}(\mathrm{n}=4)$.

wLeaching fraction $=$ effluent volume $\div$ influent volume, averaged for the entire $114 \mathrm{~d}$, pooled over P application rate of $0.5 \mathrm{~g}$ or $1.0 \mathrm{~g}(\mathrm{n}=4)$.

${ }^{v}$ Significantly different target LF $(\mathrm{n}=8)$ denoted by capital letters in column determined by analysis of variance $(P \leq 0.05)$.

uSignificantly different substrate amendment $(\mathrm{n}=8)$ denoted by lower-case letters in row determined by analysis of variance $(P \leq 0.05)$. 


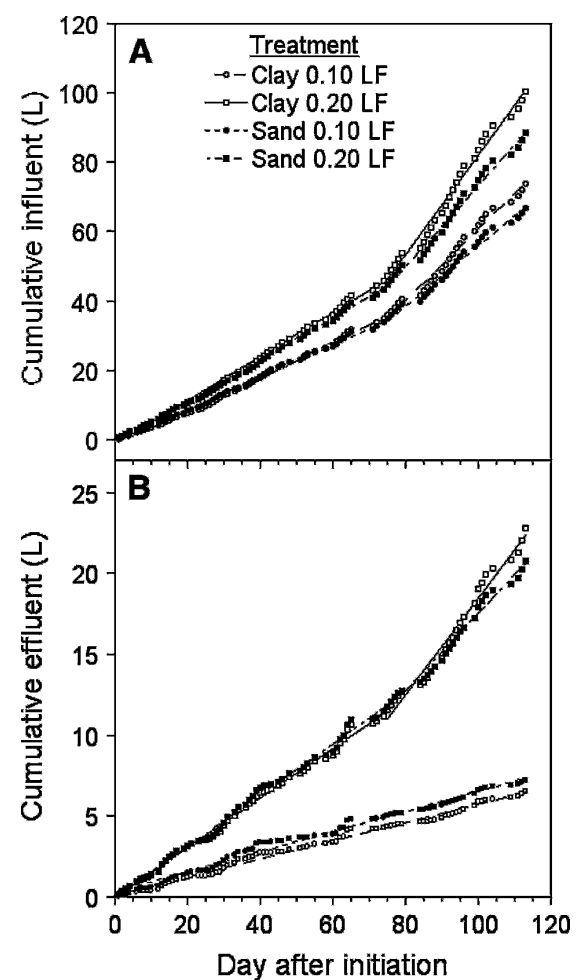

Fig. 1. Cumulative (A) influent and (B) effluent per container to maintain a target leaching fraction (LF) of 0.10 or 0.20 for Skogholm cotoneaster grown $114 \mathrm{~d}$ in a pine bark substrate amended with $11 \%$ (by volume) sand or 0.25 to $0.85 \mathrm{~mm}$ Georgiana bentonite-palygorksite mineral aggregate (clay). Linear and segmented linear models were calculated for influent [clay $(0.1$ LF: if $\times \leq 75 \mathrm{~d}$ after experiment initiation (DAI), then $\mathrm{y}=-1.6+0.5 \times, R^{2}=0.99$; if $\times$ $\geq 75$ DAI, then $y=-42.0+1.0 \times, R^{2}=0.98 ; 0.2$ LF: if $\times \leq 75 \mathrm{DAI}$, then $\mathrm{y}=-1.5+0.6 \mathrm{x}, R^{2}=$ 0.99 ; if $\times \geq 75 \mathrm{DAI}$, then $\mathrm{y}=-61.6+1.4 \times, R^{2}=$ 0.98 ); sand (0.1 LF: if $\times \leq 75$ DAI, then $y=-0.8$ $+0.5 \times, R^{2}=0.99$; if $\times \geq 75$ DAI, then $\mathrm{y}=-30.4$ $+0.9 \times, R^{2}=0.98 ; 0.2 \mathrm{LF}$ : if $\times \leq 75$, then $\mathrm{y}=-$ $1.2+0.6 \times, R^{2}=0.99$; if $\times \geq 75 \mathrm{DAI}$, then $\mathrm{y}=-$ $\left.\left.43.5+1.2 \times, R^{2}=0.98\right)\right]$ and effluent [clay $(0.1$ LF: $\mathrm{y}=0.10+0.06 \times, R^{2}=0.99 ; 0.2 \mathrm{LF}$ : if $\times$ $\leq 75$ DAI, then $\mathrm{y}=-0.01+0.15 \times, R^{2}=0.99$; if $x \geq 75$ DAI, then $y=-11.5+0.30 \times, R^{2}=0.98$ ); sand ( $0.1 \mathrm{LF}$ : $\mathrm{y}=0.29+0.06 \times, R^{2}=0.99 ; 0.2$ LF: if $\times \leq 75$ DAI, then $y=-0.05+0.16 \times$, $R^{2}=0.99$; if $\times \geq 75$ DAI, then $\mathrm{y}=-6.4+0.24 \times$, $\left.R^{2}=0.98\right)$. Irrigation was applied cyclically at 0200, 0400, and $0600 \mathrm{HR}$ eastern daylight time with an additional $670 \mathrm{~mm}$ of rain throughout the experiment.

grown in clay-amended pine bark was greater both at $0.5 \times$ or $1.0 \times \mathrm{P}$ compared with plants grown in sand-amended pine bark.

Total dry weight of Skogholm cotoneaster $($ mean $=211 \mathrm{~g} \pm 7 \mathrm{SE})$ was unaffected by target LF (data not presented). Thus, in a clay-amended substrate, plant growth was equivalent with a $50 \%$ reduction in $\mathrm{P}$ rate and LF. Interestingly, Skogholm cotoneaster grown in pine bark amended with clay required $298 \mathrm{~mL} \cdot \mathrm{g}^{-1} \pm 10 \mathrm{SE}$, whereas sandamended substrate required $341 \mathrm{~mL} \cdot \mathrm{g}^{-1} \pm 12$ SE. Pine bark amended with clay may have reduced water stress that resulted in this $15 \%$ increase in $\mathrm{WUE}_{\mathrm{P}}$ versus pine bark amended with sand. LF did not affect $\mathrm{WUE}_{\mathrm{P}}$ in this

Table 3. Effect of $P$ application rate and substrate amendment on total plant dry weight and root:top ratio of Skogholm cotoneaster grown for $114 \mathrm{~d}$ in pine bark amended (by vol.) with $11 \%$ sand (control) or 0.25 to $0.85 \mathrm{~mm}$ Georgiana bentonite-palygorksite mineral aggregate (clay). ${ }^{\mathrm{z}}$

\begin{tabular}{|c|c|c|c|c|c|c|}
\hline \multirow[b]{3}{*}{ Substrate amendment } & \multicolumn{3}{|c|}{ Total dry $\mathrm{wt}^{\mathrm{y}}(\mathrm{g})$} & \multicolumn{3}{|c|}{ Root : top ratio ${ }^{x}$} \\
\hline & \multicolumn{2}{|c|}{$P$ rate $(g)$} & \multirow[b]{2}{*}{$P$ value } & \multicolumn{2}{|c|}{$P$ rate $(g)$} & \multirow[b]{2}{*}{$P$ value } \\
\hline & 0.5 & $\overline{1.0}$ & & 0.5 & $\overline{1.0}$ & \\
\hline$\overline{\text { Clay }}$ & $245^{\mathrm{w}}$ & 230 & 0.27 & 0.21 & 0.16 & 0.02 \\
\hline Sand & 168 & 199 & 0.07 & 0.21 & 0.20 & 0.54 \\
\hline$\overline{P \text { value }}$ & 0.0001 & 0.05 & & 0.80 & 0.03 & \\
\hline
\end{tabular}

${ }^{\mathrm{z} P}$ rate and substrate amendment interaction were significant as determined by analysis of variance $(P \leq$ $0.10)$.

${ }^{\mathrm{y}}$ Total dry weight $=$ root mass $(\mathrm{g})+$ top mass $(\mathrm{g})$.

${ }^{\mathrm{x}}$ Root:top $=$ root mass $(\mathrm{g}) \div$ top mass $(\mathrm{g})$.

wPooled over target leaching fraction of 0.1 or $0.2(\mathrm{n}=8)$.

study (data not presented); however, $\mathrm{WUE}_{\mathrm{P}}$ has been shown to increase with decreasing LF (Ku and Hershey, 1992; Tyler et al., 1996).

Root : top ratio was unaffected by $P$ rate in the sand substrate (Table 3 ) indicating carbon allocation between top and root was unaffected by $P$ rate. In contrast, root : top ratio of cotoneaster grown in the clay substrate decreased from 0.21 to 0.16 when $\mathrm{P}$ rate was increased from $0.5 \times$ to $1.0 \times$, suggesting carbon allocation favored top growth. This decrease in root : top ratio resulted from a $34 \%$ increase $(11 \mathrm{~g})$ in root dry weight (data not presented) when grown with $0.5 \mathrm{~g} \mathrm{P}$ compared with $1.0 \mathrm{~g}$ P. This higher root mass at $0.5 \times \mathrm{P}$ rate could have been a result of less available $\mathrm{P}$ and greater root exploration resulting from less than optimal edaphic conditions (e.g., water and nutrients) (Brouwer, 1962). Plants grown with $1.0 \mathrm{~g} \mathrm{P}$ in sand-amended pine bark had a significantly higher root:top ratio compared with clay. Thus, at $1.0 \mathrm{~g} \mathrm{P}$, plants grown in sandamended pine bark required more proportional root dry weight to top dry weight for water and nutrient uptake (Fritter and Hay, 2002). This most likely resulted from either "stress memory" (Chaves et al., 2002) or limited nutrient availability (Brouwer, 1962).

Plant nutrient allocation. Top and root total mineral nutrient content of macronutrients $(\mathrm{P}, \mathrm{K}, \mathrm{Ca}, \mathrm{Mg})$, with the exception of $\mathrm{N}$, increased when pine bark was amended with clay versus sand-amended substrate (Table 4). Phosphorus content increased in the root $225 \%$ (25 mg) and top 105\% (139 $\mathrm{mg}$ ) in clay versus sand-amended pine bark substrate, respectively. This increase in root and top $\mathrm{P}$ content could be a result of increased substrate anion exchange capacity (AEC) when amended with clay containing palygorskite. AEC may increase with palygorskite because it has $28 \%$ to $59 \%$ of the octahedral sites and $11 \%$ or less of the tetrahedral sites filled with aluminum (A1) (Singer, 1989, and references therein) that are exposed as edge groups. Fe may also contribute to $\mathrm{P}$ sorption because the Georgiana palygorskite-bentonite mineral contributed $\approx 40 \mathrm{~g} \mathrm{Fe}$ (Oil Dri, personal communication) to a container; however, it is unknown what portion of this Fe is exposed. Both Al- and Fe-oxide minerals could result in surfacebound phosphate $\left(\equiv \mathrm{M}-\mathrm{OPO}_{3} \mathrm{H}_{2}\right.$; Essington, 2004). In addition, dissolution of Ca-phosphate minerals present in the mineral aggre- gate may contribute to available P. X-ray absorption near edge surface spectroscopy has shown that the main $\mathrm{P}$ species associated with this mineral aggregate is likely hydroxyapatite $\left[\mathrm{Ca}_{4} \mathrm{H}(\mathrm{PO})_{4} \cdot 2.5 \mathrm{H}_{2} \mathrm{O}\right]$ (Owen, 2006), which could be an available, labile source of P. The plant dry weight data, in combination with the differences in plant $\mathrm{P}$ mineral nutrient content, indicated limited substrate $\mathrm{P}$ availability may have reduced growth in sand-amended pine bark substrate.

$\mathrm{K}, \mathrm{Ca}, \mathrm{Mg}$, and $\mathrm{S}$ content in the plant top increased 38\% (569 mg), 48\% (534 mg), 54\% (203 mg), and 21\% (23 mg), respectively, when the substrate was amended with clay versus sand (Table 4). Root content of $\mathrm{K}, \mathrm{Ca}$, and $\mathrm{Mg}$ responded similarly. Micronutrient content (Fe, Mn, and B) of Skogholm cotoneaster tops also increased 50\% (6 mg), 32\% $(8 \mathrm{mg})$, and $26 \%$ (1 mg), respectively, when grown in clay-amended substrate (Table 4 ). Increased mineral nutrient uptake could have been a result of improved cation retention in the clay- versus sand-amended substrate. Laiche and Nash (1990) reported increased extractable sodium $(\mathrm{Na})$ and $\mathrm{Ca}$ with incorporation of arcillite into a pine bark substrate. Warren and Bilderback (1992) also hypothesized that increased growth of Sunglow azalea with calcined clay (arcillite) amended pine bark was the result of increased $\mathrm{K}$ and $\mathrm{Mg}$ plant absorption. This increase in cation content could have also been a function of substrate nutrient buffering capacity. Palygorskite and montmorillonite have a cation exchange capacity of $30 \mathrm{cmol}_{\mathrm{c}} \cdot \mathrm{kg}^{-1}$ or less (Tan, 1998) and $\approx 115 \mathrm{cmol}_{\mathrm{c}} \cdot \mathrm{kg}^{-1}$, respectively (Borchardt, 1998).

Decreasing the target LF from 0.2 to 0.1 resulted in a $22 \%(37 \mathrm{mg})$ and $29 \%(11 \mathrm{mg})$ increase in $\mathrm{K}$ and $\mathrm{S}$ root content, respectively, whereas $\mathrm{N}, \mathrm{P}$, and $\mathrm{B}$ were unaffected (Table 5). In addition, root $\mathrm{Ca}(136 \mathrm{mg} \pm 11 \mathrm{sE}), \mathrm{Mg}$ (77 $\mathrm{mg} \pm 6 \mathrm{SE}$ ), and micronutrient content were unaffected (data not presented). Even with increased leaching at $0.2 \mathrm{LF}$, we propose there was adequate $\mathrm{N}, \mathrm{P}$, and micronutrients for plant uptake. This increase in $\mathrm{K}$ and $\mathrm{S}$ plant content was most likely a function of increased nutrient availability resulting from decreased leaching. Both ions ( $\mathrm{K}$ and $\mathrm{S}$ ) are mobile in similar sandy soil systems where the cation $\left(\mathrm{K}^{+}\right)$and anion $\left(\mathrm{SO}_{4}{ }^{2-}\right)$ are subject to leaching because of their low to moderate affinity for exchange sites on clay minerals (Havlin et al., 1999). 
Table 4. Mineral nutrient content of root and top of Skogholm cotoneaster grown $114 \mathrm{~d}$ in a pine bark substrate amended with $11 \%$ (by vol.) sand or 0.25 to $0.85 \mathrm{~mm}$ Georgiana bentonite-palygorksite mineral aggregate (clay). ${ }^{\mathrm{z}}$

\begin{tabular}{|c|c|c|c|c|c|c|c|c|c|c|}
\hline \multirow[b]{2}{*}{ Substrate amendment } & \multicolumn{7}{|c|}{ Macronutrient (mg) } & \multicolumn{3}{|c|}{ Micronutrient (mg) } \\
\hline & $\mathrm{N}$ & $\mathrm{P}$ & $\mathrm{K}$ & $\mathrm{Ca}$ & $\mathrm{Mg}$ & $\mathrm{Na}$ & $\mathrm{S}$ & $\mathrm{Fe}$ & $\mathrm{Mn}$ & B \\
\hline Clay & $136^{y}$ & 45 & 225 & 156 & 86 & 65 & 46 & 4 & 6 & 0.5 \\
\hline \multicolumn{11}{|l|}{ Top } \\
\hline Clay & 2011 & 268 & 2055 & 1638 & 580 & 235 & 133 & 18 & 33 & 4.9 \\
\hline Sand & 1871 & 129 & 1486 & 1104 & 377 & 154 & 110 & 12 & 25 & 3.9 \\
\hline
\end{tabular}

${ }^{\mathrm{z}}$ Each container had $54 \mathrm{~g}$ of either $19 \mathrm{~N}-0.9 \mathrm{P}-6.4 \mathrm{~K}$ or $19 \mathrm{~N}-1.8 \mathrm{P}-6.4 \mathrm{~K}$ controlled-release fertilizer surface applied.

${ }^{\mathrm{y}}$ Substrate amendment main effect $(\mathrm{n}=16)$; nutrient content $=$ nutrient concentration $\left(\mathrm{mg} \cdot \mathrm{kg}^{-1}\right) \times$ plant part dry weight $(\mathrm{g})$.

Table 5. Effect of phosphorus (P) application rate and target leaching fraction (LF) on top and root mineral nutrient content $(\mathrm{n}=16)$ of Skogholm cotoneaster grown $114 \mathrm{~d}$ with $54 \mathrm{~g}$ of either $19 \mathrm{~N}-1.8 \mathrm{P}-6.4 \mathrm{~K}$ $[1.0 \times(1.0 \mathrm{~g} \mathrm{P})]$ or $19 \mathrm{~N}-0.9 \mathrm{P}-6.4 \mathrm{~K}[0.5 \times(0.5 \mathrm{~g} \mathrm{P})]$ controlled-release fertilizer surfaced applied.

\begin{tabular}{lccccr}
\hline & \multicolumn{5}{c}{ Nutrient content $(\mathrm{mg})$} \\
\cline { 2 - 6 } Main effect & $\mathrm{N}$ & $\mathrm{P}$ & $\mathrm{K}$ & $\mathrm{S}$ & $\mathrm{B}$ \\
\hline Target LF & & Root & & \\
$\quad 0.1$ & $164^{\mathrm{z}}$ & 33 & 208 & 49 & 0.5 \\
0.2 & 137 & 32 & 171 & 38 & 0.5 \\
\hline$P$ value & 0.15 & 0.98 & 0.03 & 0.03 & 0.23 \\
\hline P rate (g) & & & Top & \\
0.5 & $1697^{\mathrm{z}}$ & 187 & 1675 & 116 & 4.1 \\
1.0 & 2184 & 210 & 1866 & 127 & 4.6 \\
\hline$P$ value & 0.005 & 0.05 & 0.04 & 0.23 & 0.03 \\
\hline
\end{tabular}

${ }^{\mathrm{z}}$ Nutrient content $=$ nutrient concentration $\left(\mathrm{mg} \cdot \mathrm{kg}^{-1}\right) \times$ plant part dry weight $(\mathrm{g})$.

When $\mathrm{P}$ application rate was decreased from $1.0 \times$ to $0.5 \times$, top $\mathrm{N}, \mathrm{P}, \mathrm{K}$, and $\mathrm{B}$ decreased 22\% (487 mg), 11\% (23 mg), $10 \%(191 \mathrm{mg})$, and $11 \%(0.5 \mathrm{mg})$, respectively (Table 5). Top Ca (1371 mg $\pm 97 \mathrm{SE})$, $\mathrm{Mg}(478 \mathrm{mg} \pm 35 \mathrm{sE})$, and micronutrient content, with the exception of $\mathrm{B}$, were not significantly affected by $\mathrm{P}$ application rate. A reduction in available $\mathrm{P}$ could have limited plant growth, thus lowering nutrient demand of Skogholm cotoneaster and subsequent uptake. On the contrary, the $16 \%$ reduction in plant growth associated with low P application could explain the reduction in nutrient uptake.

Effluent phosphorus. Over 114 d, effluent concentration of DRP (mean $=0.8 \mathrm{mg} \cdot \mathrm{L}^{-1} \pm$ $0.02 \mathrm{SE}$ ) was unaffected by rate of $\mathrm{P}$ application (data not presented). Tyler et al. (1996) also reported decreasing fertilizer application rate as an ineffective means of decreasing effluent $\mathrm{P}$ concentration. In contrast, reducing target LF from 0.2 to 0.1 reduced mean DRP effluent concentration $8 \%\left(0.1 \mathrm{mg} \cdot \mathrm{L}^{-1}\right)$ (data not presented). However, average daily DRP effluent concentration increased 58\% in a clay- $\left(1.0 \mathrm{mg} \cdot \mathrm{L}^{-1} \pm 0.02 \mathrm{SE}\right)$ versus sand$\left(0.6 \mathrm{mg} \cdot \mathrm{L}^{-1} \pm 0.02 \mathrm{sE}\right)$ amended substrate over the course of the study (Fig. 2). In clayamended substrate, daily effluent DRP concentration remained notably constant at $1.0 \mathrm{mg} \cdot \mathrm{L}^{-1}$ after $60 \mathrm{DAI}$, whereas DRP concentration from sand-amended substrate decreased from 0.9 to $0.2 \mathrm{mg} \cdot \mathrm{L}^{-1}$ from 60 to 100 DAI. This decrease in effluent DRP concentration is probably the result of decreased $\mathrm{P}$ release from the CRF. This decreased $\mathrm{P}$ release from the CRF is also believed to occur in the clay-amended sub- strate; however, we speculate that apatite or $\mathrm{Al}$ - and $\mathrm{Fe}$-sorbed $\mathrm{P}$ was released to maintain $P$ concentration in the bulk solution of the clay-amended substrate.

Cumulative effluent DRP decreased 67\% and $64 \%$ when irrigated to maintain a $0.1 \mathrm{LF}$ versus 0.2 LF in a clay- and sand-amended substrate, respectively (Table 6). Effluent DRP content was strongly correlated with leachate volume $(r=0.73, P \leq 0.0001)$. These results are similar to the $58 \%$ decrease in effluent $\mathrm{P}$ reported by Tyler et al. (1996) when growing Skogholm cotoneaster in 3.8$\mathrm{L}$ containers with a low $(0.0$ to 0.2$)$ versus high (0.4 to 0.6$)$ LF. Effluent from the clayamended substrate contained $75 \%(3 \mathrm{mg}$ ) to $90 \%$ (10 mg) more DRP than the sandamended substrate with a 0.1 or 0.2 target LF, respectively.

At $0.1 \mathrm{LF}$, the rate of effluent DRP loss remained relatively constant $\left(0.04 \mathrm{mg} \cdot \mathrm{d}^{-1}\right)$ regardless of substrate until 58 DAI (Fig. 2B). Until 58 DAI with a 0.2 target LF, the rate of effluent DRP loss was $0.10 \mathrm{mg} \cdot \mathrm{d}^{-1}$ and 0.08 $\mathrm{mg} \cdot \mathrm{d}^{-1}$ for sand- and clay-amended substrate, respectively. Thus, reducing the LF by $50 \%$ reduced effluent DRP greater than $50 \%$. Tyler et al. (1996) reported similar results. Rain events associated with tropical storms and hurricanes resulted in an average 300\% increase in rate of effluent lost between 58 and 64 DAI (22 to 29 July) in all treatments. In addition, data were lost from 65 to $71 \mathrm{DAI}$ (29 July to 4 Aug.) as a result of these storms. Rates of effluent DRP loss at 71 DAI were equivalent to losses recorded at $54 \mathrm{DAI}$ for all treatments. However, 71 or greater DAI, in a clay-amended substrate effluent, DRP loss was $50 \%$ to $180 \%$ greater when a 0.1 or 0.2

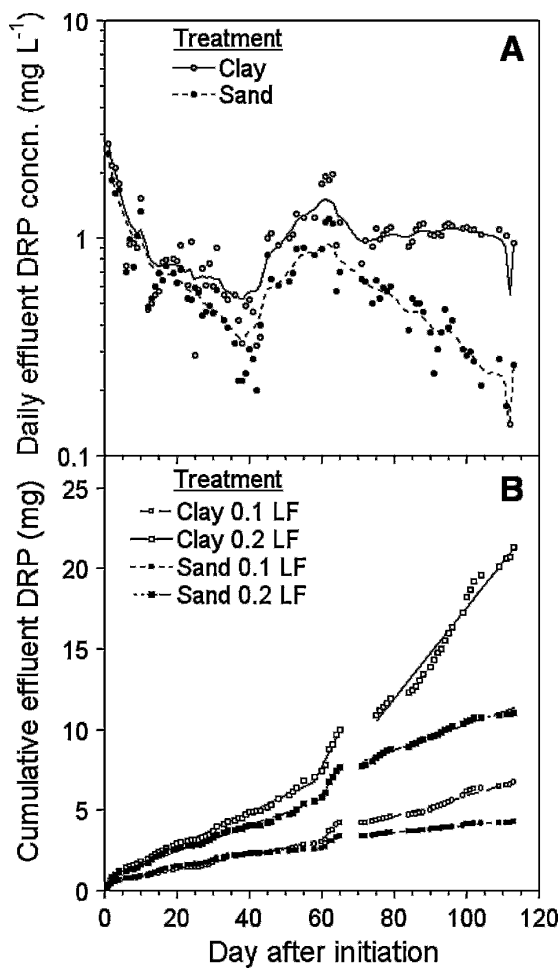

Fig. 2. Daily (A) and cumulative (B) dissolved reactive phosphorus (DRP) concentration and content, respectively, of effluent from Skogholm cotoneaster grown $114 \mathrm{~d}$ in pine bark substrates amended with $11 \%$ (by volume) sand or 0.25 to $0.85 \mathrm{~mm}$ Georgiana bentonite-palygorksite mineral aggregate (clay). in which a 0.1 or 0.2 target leaching fraction was maintained. Segmented linear models were calculated for each treatment. Clay (0.1 LF: if $\times$ $\leq 58 \mathrm{~d}$ after experiment initiation (DAI), then $\mathrm{y}=0.4+0.04 \times, \mathrm{R}^{2}=0.98 ;$ if $58 \mathrm{DAI} \leq \times \leq 65$ DAI, then $y=-9.4+0.21 \times, R^{2}=0.97$; if $x \geq 71$ DAI, then $\mathrm{y}=-0.6+0.06 \times, \mathrm{R}^{2}=0.96 ; 0.2 \mathrm{LF}$ : if $\times \leq 58$ DAI, then $\mathrm{y}=0.7+0.10 \times, \mathrm{R}^{2}=0.99$; if $58 \mathrm{DAI} \leq \times \leq 65 \mathrm{DAI}$, then $\mathrm{y}=-19.7+0.46 \times$, $\mathrm{R}^{2}=0.96$; if $\mathrm{x} \geq 71$ DAI, then $\mathrm{y}=-10.7+$ $\left.0.28 \times, \mathrm{R}^{2}=0.97\right)$; sand (0.1 LF: if $\times \leq 58 \mathrm{DAI}$, then $\mathrm{y}=0.6+0.04 \times, \mathrm{R}^{2}=0.96$; if $58 \mathrm{DAI} \leq \times$ $\leq 65$ DAI, then $\mathrm{y}=-5.3+0.13 \times, \mathrm{R}^{2}=0.91$; if $\times$ $\geq 71$ DAI, then $\mathrm{y}=1.8+0.03 \times, \mathrm{R}^{2}=0.98 ; 0.2$ LF: if $\times \leq 58$ DAI, then $\mathrm{y}=0.8+0.08 \times, \mathrm{R}^{2}=$ 0.99 ; if $58 \mathrm{DAI} \leq \times \leq 65$, then $\mathrm{y}=-14.4+$ $0.34 \times, \mathrm{R}^{2}=0.95$; if $\times \geq 71 \mathrm{DAI}$, then $\mathrm{y}=2.3+$ $0.08 \times, \mathrm{R}^{2}=0.97$.

target LF, respectively, was maintained compared with the sand-amended substrate. This increase in effluent DRP content may have been the result of desorbed or dissolved $\mathrm{P}$ 
from the $\mathrm{Fe}$ or $\mathrm{Al}$ oxides or apatite resulting in a substrate-solution chemical equilibrium producing a higher substrate solution $\mathrm{P}$ concentration, which was reflected in the higher effluent $\mathrm{P}$ concentration $\left(1 \mathrm{mg} \cdot \mathrm{L}^{-1}\right)$. Shariatmadari and Mermut (1999) examined P sorption in similar clays, palygorskite- and montmorillonite-calcite, where 8.8 and 9.2 $\mathrm{cmol} \cdot \mathrm{kg}^{-1}$ was sorbed, respectively. Thus, $\mathrm{P}$ could have desorbed from sorption sites or dissolved from the inherent Ca.P minerals. Regardless of $\mathrm{P}$ effluent content or concentration, cumulative effluent DRP was significantly greater in clay- versus sand-amended substrate whether irrigated to maintain a 0.1 or 0.2 target LF (Table 6). In addition, a reduction in $\mathrm{P}$ application rate from $1.0 \times$ to $0.5 \times$ increased PUE $54 \%$ in a clay-amended substrate; however, the reduction in $\mathrm{P}$ appliamended substrate where PUE increased $11 \%$ (Table 6).

Phosphorus budgets. Of the $1 \mathrm{~g}$ of $\mathrm{P}$ applied, $32 \%$ to $59 \%$ was recovered, whereas $36 \%$ to $110 \%$ of the $0.5 \mathrm{~g}$ of $\mathrm{P}$ was recovered by the plant across LF and substrate treatment (Table 7). Tyler et al. (1996) and Warren et al. (1995) also reported low P recovery percentages. Within each target LF, effluent DRP loss was unaffected by rate of P application rate was less effective in a sand-

cation. However, effluent DRP losses were reduced $69 \%$ and $61 \%$ when pine bark was amended with clay or sand, respectively. Skogholm cotoneaster P content increased $113 \%$ and $135 \%$ for tops and roots, respectively, when grown in clay-amended substrate compared with sand. Likewise, $\mathrm{P}$ remaining in the substrate increased 332\% when amended with clay compared with sand. Phosphorus release from the fertilizer prills was unaffected by either leaching fraction or substrate. The fertilizer prills contained $9 \%$ (mean $=46 \mathrm{mg} \pm 4 \mathrm{SE})$ and $12 \%$ (mean $=120 \mathrm{mg} \pm 4 \mathrm{SE}$ ) of the original $0.5 \times$ or $1.0 \times$ of $\mathrm{P}$ applied to each container, respectively, when pooled over substrate and LF. Plants grown with the clay-amended substrate and the $0.5 \times \mathrm{P}$ rate had the highest PUE, $82 \%$ and $107 \%$ at 0.1 and $0.2 \mathrm{LF}$, respectively, followed by the $1.0 \times \mathrm{P}$ rate, $39 \%$ and $44 \%$ at 0.1 and $0.2 \mathrm{LF}$, respectively (Table 7). These reported efficiencies are greater than $32 \%$ PUE reported by Lea-Cox and Ristvey (2003) when applying $0 \mathrm{~g} \mathrm{P}$ to Karen azalea (Rhododendron L. 'Karen') or the $43 \%$ PUE reported by Warren et al. (1995) using resin-coated CRF P to grow Sunglow azalea.

In summary, clay-amended substrates increased both water and mineral nutrient

Table 6. Cumulative effluent dissolved reactive phosphorus (DRP) and PUE of Skogholm cotoneaster plant grown $114 \mathrm{~d}$ in a pine bark substrate amended with $11 \%$ (by vol.) coarse sand or 0.25 to $0.85 \mathrm{~mm}$ Georgiana bentonite-palygorksite (clay) in which $0.5 \mathrm{~g}(0.5 \times)$ or $1.0 \mathrm{~g}(1.0 \times) \mathrm{P}$ was applied and a 0.1 or 0.2 target leaching fraction (LF) was maintained.

\begin{tabular}{|c|c|c|c|}
\hline \multirow[b]{2}{*}{ Treatment } & \multicolumn{2}{|c|}{ Substrate amendment } & \multirow[b]{2}{*}{$P$ value } \\
\hline & Clay & Sand & \\
\hline Target LF & \multicolumn{2}{|c|}{ Cumulative effluent $\mathrm{DRP}^{\mathrm{z}}(\mathrm{mg})$} & \\
\hline 0.1 & $7^{2}$ & 4 & 0.02 \\
\hline 0.2 & 21 & 11 & 0.0001 \\
\hline$\overline{P \text { value }}$ & 0.0001 & 0.0004 & \\
\hline P rate $(\mathrm{g})$ & \multicolumn{2}{|c|}{ Phosphorus uptake efficiency ${ }^{y}(\%)$} & \\
\hline 0.5 & $95^{y}$ & 31 & 0.001 \\
\hline 1.0 & 41 & 20 & 0.0002 \\
\hline$P$ value & 0.003 & 0.003 & \\
\hline
\end{tabular}

${ }^{\mathrm{z}} \sum\left[\right.$ effluent $\mathrm{P}$ concentration $\left(\mathrm{mg} \cdot \mathrm{L}^{-1}\right) \times$ effluent volume $\left.(\mathrm{L})\right]$ for the entire $114 \mathrm{~d}$, pooled over $\mathrm{P}$ application rate of $0.5 \mathrm{~g}$ or $1.0 \mathrm{~g}(\mathrm{n}=4)$.

${ }^{\mathrm{y}} \mathrm{P}$ uptake efficiency $=[$ plant $\mathrm{P}(\mathrm{mg}) \div(\mathrm{P}$ applied $\{\mathrm{mg}\}-\mathrm{P}$ remaining in fertilizer prill $\{\mathrm{mg}\}-$ substrate $\mathrm{P}\{\mathrm{mg}\})] \times 100$, pooled over target leaching fraction of 0.1 or $0.2(\mathrm{n}=4)$.

Table 7. A partition of phosphorus $(\mathrm{P})(\mathrm{n}=2)$ for Skogholm cotoneaster grown $114 \mathrm{~d}$ in pine bark substrates amended with $11 \%$ (by vol.) sand or 0.25 to $0.85 \mathrm{~mm}$ Georgiana bentonite-palygorksite mineral aggregate (clay). ${ }^{2}$

\begin{tabular}{|c|c|c|c|c|c|c|c|c|}
\hline \multirow{3}{*}{$\begin{array}{l}\text { Phosphorus } \\
\text { partition (mg) }\end{array}$} & \multicolumn{4}{|c|}{ Clay } & \multicolumn{4}{|c|}{ Sand } \\
\hline & \multicolumn{2}{|c|}{$0.1 \mathrm{LF}$} & \multicolumn{2}{|c|}{$0.2 \mathrm{LF}$} & \multicolumn{2}{|c|}{$0.1 \mathrm{LF}$} & \multicolumn{2}{|c|}{$0.2 \mathrm{LF}$} \\
\hline & $\overline{0.5 \times P}$ & $1.0 \times \mathrm{P}$ & $\overline{0.5 \times P}$ & $1.0 \times \mathrm{P}$ & $\overline{0.5 \times P}$ & $1.0 \times \mathrm{P}$ & $\overline{0.5 \times P}$ & $1.0 \times \mathrm{P}$ \\
\hline Effluent & 7 & 6 & 21 & 21 & 3 & 5 & 10 & $\overline{12}$ \\
\hline \multicolumn{9}{|l|}{ Cotoneaster } \\
\hline Root & 45 & 44 & 54 & 46 & 20 & 22 & 18 & 20 \\
\hline Top & 255 & 253 & 308 & 281 & 104 & 142 & 120 & 149 \\
\hline Substrate & 65 & 66 & 85 & 78 & 13 & 16 & 18 & 21 \\
\hline Fertilizer prill & 46 & 118 & 54 & 130 & 31 & 119 & 52 & 114 \\
\hline PUE $^{y}(\%)$ & 82 & 39 & 107 & 44 & 29 & 20 & 34 & 21 \\
\hline \multicolumn{9}{|l|}{ Recovered } \\
\hline Phosphorus $^{x}$ & 417 & 488 & 521 & 557 & 172 & 304 & 218 & 316 \\
\hline Percent $^{\mathrm{w}}$ & 88 & 51 & 110 & 59 & 36 & 32 & 46 & 33 \\
\hline
\end{tabular}

${ }^{\mathrm{z}}$ Each container had $1.0 \times(1000 \mathrm{mg})$ or $0.5 \times(500 \mathrm{mg}) \mathrm{P}$ surface incorporated at the initiation of the experiment and a target leaching fraction (LF) of 0.1 or 0.2 .

${ }^{\text {yPUE }}(\mathrm{P}$ uptake efficiency $)=[$ Plant $\mathrm{P}(\mathrm{mg}) \div(\mathrm{P}$ applied $\{\mathrm{mg}\}-\mathrm{P}$ remaining in fertilizer prill $\{\mathrm{mg}\}-$ substrate $\mathrm{P}\{\mathrm{mg}\})] \times 100$.

${ }^{\mathrm{x}}$ Recovered $\mathrm{P}=$ effluent $(\mathrm{mg})+$ plant $(\mathrm{mg})+$ substrate $(\mathrm{mg})+$ fertilizer prill $(\mathrm{mg})$.

${ }^{\text {w }}$ Percent recovered $\mathrm{P}=[$ recovered $\mathrm{P}(\mathrm{mg}) \div \operatorname{applied} \mathrm{P}(\mathrm{mg})] \times 100$. buffering capacities of the substrate. Mineral nutrient content of $\mathrm{P}, \mathrm{K}, \mathrm{Ca}, \mathrm{Mg}, \mathrm{S}$, and $\mathrm{Mn}$ in Skogholm cotoneaster increased in clayamended substrate with a $100 \%$ increase in total plant $\mathrm{P}$ content in clay-amended compared with sand-amended substrate. This resulted in a $20 \%$ to $60 \%$ increase in PUE despite increased cumulative effluent DRP content and concentration. Clay may act as a slow-release form of $\mathrm{P}$ that reduces environmental impact while supplying the plant a portion of needed $P$.

\section{Literature Cited}

Borchardt, G. 1998. Smectites, p. 675-728. In: Dixon, J.B. and S.B. Weed (eds.). Minerals in the soil environment 2nd Ed. Book Series No. 1. Soil Sci. Soc. Amer., Madison, WI.

Brady, N.C. and R.R. Weil. 1999. The nature and properties of soils. 12th Ed. Prentice Hall, Upper Saddle River, NJ.

Brouwer, R. 1962. Nutritive influence on distribution of dry matter in the plant. Neth. J. Agr. Sci. 10:399-408.

Carlile, W.R. and I. Bedford. 1988. Plant growth in container medium amended with calcined clay. Acta Hort. 221:117-132.

Chaves, M.M., J.S. Pereira, J. Maroco, M.L. Rodrigues, C.P.P. Ricardo, M.L. Osorio, I. Carvalho, T. Faria, and C. Pinheiro. 2002. How plants cope with water stress in the field? Photosynthesis and growth. Ann. Bot. (Lond.) 89:907-916.

Epstein, E. and A.J. Bloom. 2005. Mineral nutrition of plants: Principles and perspectives. 2nd Ed. Sinauer Assoc., Sunderland, MA.

Essington, M.E. 2004. Soil and water chemistry: An integrative approach. CRC Press LLC, Boca Raton, FL.

Fonteno, W.C. and T.E. Bilderback. 1993. Impact of hydrogel on physical properties of coarsestructured horticultural substrates. J. Amer. Soc. Hort. Sci. 118:217-222.

Fritter, A.H. and R.K.M. Hay. 2002. Environmental physiology of plants. Academic Press, San Diego, CA.

Groves, K.M., S.L. Warren, and T.E. Bilderback. 1998a. Irrigation volume, application, and controlled-release fertilizers: I. Effect on plant growth and mineral nutrient content in containerized plant production. J. Environ. Hort. 16:176-181.

Groves, K.M., S.L. Warren, and T.E. Bilderback. 1998b. Irrigation volume, application, and controlled-release fertilizers: II. Effect on substrate solution nutrient concentration and water efficiency in containerized plant production. J. Environ. Hort. 16:182-188.

Havlin, J.L., J.D. Beaton, S.L. Tisdale, and W.L. Nelson. 1999. Soil fertility and fertilizers: An introduction to nutrient management. 6th Ed. Prentice Hall, Upper Saddle River, NJ.

Ku, C.S.M. and D.R. Hershey. 1992. Leachate electrical conductivity and growth of potted geranium with leaching fractions of 0 and 0.4 . J. Amer. Soc. Hort. Sci. 117:893-897.

Laiche A.J., Jr. and V.E. Nash. 1990. Evaluation of composted rice hulls and a lightweight clay aggregate as components of container-plant growth media. J. Environ. Hort. 8:14-18.

Lea-Cox, J.D. and A.G. Ristvey. 2003. Why are nutrient uptake efficiencies so low in ornamental plant production? Proc. Southern Nursery Assoc. Res Conf., 48th Annu. Rpt. p.116-122.

Marini, R.P. 1999. Are nonsignificant differences really not significant. HortScience 34:761-762. 
Milks, R.R., W.C. Fonteno, and R.A. Larson. 1989. Hydrology of horticultural substrates: I. Predicting physical properties of media in containers. J. Amer. Soc. Hort. Sci. 114:53-56.

Moll, W.F. and G.R. Goss. 1997. Mineral carriers for pesticides: Their characteristics and uses. Standard Tech. Publ. 943. Amer. Soc. Testing and Materials, West Conshohocken, PA.

Murphy, J. and J.P. Riley. 1962. A modified single solution method for the determination of phosphate in natural waters. Anal. Chim. Acta 27:31-36.

Owen J.S., Jr. 2006. Clay-amended soilless substrates: Increasing water and nutrient efficiency in containerized crop production. North Carolina State Univ., Raleigh, NC. PhD Diss.

Riviere, L.M., J.C. Foucard, and F. Lemaire. 1990. Irrigation of container crops according to the substrate. Scientia Hort. 43:339-349.

Shariatmadari, H. and A.R. Mermut. 1999. Magnesium- and silicon-induced phosphate desorption in smectite-, palygorskite-, and sepiolite-calcite systems. Soil Sci. Soc. Amer. J. 63:1167-1173.

Shaviv, A. and R.L. Mikkelsen. 1993. Controlledrelease fertilizers to increase efficiency of nutrient use and minimize environmental degradation-A review. Fert. Res. 35:1-12.
Singer, A. 1998. Palygorskite and sepiolite group minerals, p. 829-872. In: Dixon, J.B. and S.B. Weed (eds.). Minerals in the soil environment. 2nd Ed. Book Series No. 1. Soil Sci. Soc. Amer., Madison, WI.

Sonneveld, C., J. van den Ende, and P.A. van Dijk 1974. Analysis of a growing media by means of a $1: 1 \frac{1}{2}$ volume extract. Commun. Soil Sci. Plant Anal. 5:183-202.

Tan, K.H. 1998. Principles of soil chemistry. 3rd Ed. Marcel Dekker, Inc., New York, NY.

Tyler, H.H., S.L. Warren, and T.E. Bilderback. 1996. Reduced leaching fractions improve irrigation use efficiency and nutrient efficacy. J. Environ. Hort. 14:199-204.

USEPA. 1986. Quality criteria for water. Office of Water Regulation and Standards, U.S. Environ. Protection Agency 440/5-86-001, Washington, DC.

Warren, S.L. and T.E. Bilderback. 1992. Arcillite: Effect on chemical and physical properties of pine bark substrate and plant growth. J. Environ. Hort. 10:63-69.

Warren, S.L. and T.E. Bilderback. 2005. More plants per gallon: Getting more out of water. HortTechnology 15:14-18.

Warren, S.L., T.E. Bilderback, and H.H. Tyler. 1995. Efficacy of three nitrogen and phospho- rus sources in container grown azalea production. J. Environ. Hort. 13:147-151.

Williams, K.A. and P.V. Nelson. 1997. Using precharged zeolite as a source of potassium and phosphate in a soilless container medium during potted chrysanthemum production. J. Amer. Soc. Hort. Sci. 122:703708.

Williams, K.A. and P.V. Nelson. 2000. Phosphate and potassium retention and release during chrysanthemum production from precharged materials: II. Calcined clay and brick chips. J. Amer. Soc. Hort. Sci. 125:757764.

Yeager, T., T. Bilderback, D. Fare, C. Gilliam, A. Niemiera, and K. Tilt. 1997. Best management practices-guide for producing containergrown plants. Southern Nursery Assoc, Atlanta, GA.

Yeager, T.H. and R.D. Wright. 1982. Phosphorus requirements of Ilex crenata Thunb. cv. Helleri grown in a pine bark medium. J. Amer. Soc. Hort. Sci. 107:558-562.

Zhang, Y., L. Kuhns, J.P. Lynch, and K.M. Brown. 2002. Application methods affects water application efficiency of spray stake irrigated containers. J. Environ. Hort. 28: 625-627. 